HStud 25 (2011)2, 303-314

DOI: 10.1556/HStud.25.2011.2.10

\title{
HUNGARICA IN CAMBRIDGE LIBRARIES
}

\author{
GEORGE GÖMÖRI \\ University of Cambridge \\ Cambridge, UK
}

\begin{abstract}
In the following article I offer a survey of early Hungarica source materials in the Cambridge libraries, as well as a brief history of some of the major acquisitions.
\end{abstract}

Keywords: Hungarica, Cambridge, Hungarian studies, Hungarian history, source materials, acquisition history

In 2004 I organised a little exhibition in the University Library based on the pre-1850 Hungarian holdings of the library. While it did not have wide publicity, I managed to assemble and put on display about twenty-five interesting items, some of them never shown to the public. I am mentioning this fact for the simple reason that now I would like to survey only early Hungarica in Cambridge libraries, that is rare codices and books whether in Hungarian or Latin, with the odd book in English and some MSS thrown in for good measure.

The two best Hungarian collections are, as one would expect, in the library of Trinity College and in the University Library. Trinity, of course has great holdings in almost all fields and it is not a surprise that they have some rare Hungarica, copies of which can be found only in the Bodleian or in the British Library. The Wren Library holds a Corvina, one of the eight Corvinas now in England; it is Titus Livius, Historiae Romanae decas I (Cod.1235.0.4.4), copied some time between 1450 and 1470 which has inscriptions by various hands from 1496 and 1552. While it was part of King Matthias Corvinus's world-famous library, reputed to contain 2000 codexes, experts claim that it originates not from the territory of historical Hungary but from Northern Italy and was probably commissioned by the King (Pongrácz, 1912, 1-7). No other incunabula is extant in the library, but there are a number of 16th century Hungarica, beginning with a 1543 edition of Bonfini, several works by Johannes Honterus from Transylvania (e.g., Rudimenta cosmographiae, 1546), two books by the eccentric Bishop turned Imperial diplomat Andreas Dudith who left the Catholic Church for the sake of a Polish lady and finished his life in Breslau/Wrocław. While one of Dudith's books, 
Vita Reginaldi Poli (Venice, 1563) was a translation from Ludovico Beccadelli's Italian biography, it was also based on Dudith's earlier visit to England (ÚMIL I.: 470). There are also books of Hungarian Protestant theologians, much read and sometimes published in England. Very popular amongst these was István Szegedi Kis, known either as "Kis" or "Szegedinus", a great compiler of biblical and other theological texts; a copy of his Loci Communes (Basle, 1585) bears on its cover the coat-of-arms of Lord Burghley. (Szegedi Kis's works, by the way, can be found in many Oxford or Cambridge college libraries.) Another Hungarian, Izsák Fegyverneki, better known as "Feguernekinus", became known in England also thanks to the Basle connection - it was there that his Enchiridion was first published in 1595. The Wren Library of Trinity owns two more books by Fegyverneki, but these were published later, in 1604 and 1613, respectively - I am mentioning them for the sole reason that one of these (probably the 1604 edition) belonged to a distinguished scholar of Trinity, the young Isaac Newton.

Two dictionaries which contain a Hungarian vocabulary are the five-language Dictionarium quinque Nobilissimarum Europae linguarum (Venice, 1595) of Faustus Verantius which in its Appendix also prints prayers such as "Our Father" and "Hail Mary" in Hungarian, and the eleven-language dictionary of Calepinus. The latter's first edition (Lyon, 1585) are extant in two Cambridge libraries, in the University Library and in Sidney Sussex; as for the Wren Library it has the two volumes of the 1605 edition. But Trinity holds some Hungarian dictionaries and grammars which came from the same source and were part of an exceptional gift to the library: I am speaking about the 17th century medical doctor and scholar John Mapletoft's gift. It consists of three books by Albert Molnár Szenci: his Latin/Hungarian-Hungarian/Latin dictionary of 1604 published in Hanau, the Hungarian Bible of Oppenheim (1612) and the trilingual Latin-Greek-Hungarian dictionary of Heidelberg (1621). Molnár's place in the history of Hungarian literature is assured mainly by his translations of the Psalms of David, but he also translated the Institutions... Jean Calvin's main work into Hungarian (I found some years ago a copy inscribed for George Abbot, Abp of Canterbury, in the Lambeth Library) and was an industrious and efficient linguist. It was not Mapletoft himself who acquired all these books but his uncle Nicholas Ferrar of Little Gidding, or/and his cousin Nicholas Ferrar junior. (In the trilingual dictionary the latter inscribed his name with the date "1638", Gömöri, 1978, 298.) The Hungarian dictionaries and Bible were purchased by the Ferrars because their grand plan was to edit Bible concordances in all European languages. After the death of the older Nicholas Ferrar in 1637 it was his nephew Nicholas Ferrar the younger, who continued his work until his untimely death in 1640. This included, to prove his exceptional linguistic abilities, a New Testament concordance in 24 languages (Peckard, 1790, 263), samples of which have survived in Clare College Archives. The fourteen-line Hungarian text, interlined with English, is chosen 
from St. John's Testament, and it was most likely copied out of the Hungarian Bible by the above mentioned younger Nicholas Ferrar (Gömöri, 1993, 249).

Speaking of Hungarian Bibles, we should digress here, because there are more original Hungarian Bibles extant in Cambridge than in Amsterdam. This is partly due to the twentieth-century transfer of the British and Foreign Bible Society's library to the Cambridge University Library. In that collection there is a copy of the first complete, so-called Károli Bible published in 1591, also several 17th century editions of the Bible, with or without inscriptions. One of these bears the signature of John Huniades, who must be the son of Johannes Huniades (Bánfihunyadi), a goldsmith turned alchemist and experimental chemist whom Lilly called "one of the most learned people" he had ever met. The older Huniades was at one point Sir Kenelm Digby's assistant and later taught chemistry in Gresham College but was not a rich man; his son, on the other hand, who also dabbled in alchemy, was a shrewd money-lender who died in 1696, had become very wealthy indeed. Amongst the Bible Society possessions there is a Hungarian bible from the 18th century (published in Utrecht in 1747), which is of particular interest. The owner, one Johannes Mezö, came to England in the middle of the century as a Hussar to the Duke of Cumberland and having settled down in this country married an English girl, called Diana. The wedding took place, as an inscription in his copy of the Bible shows, on November 5, 1754. Mező, who may have changed his name later to "Field", lived thereafter in Kensington where his wife lost three newborn babies - this transpires from the last empty pages of the Bible where the bereaved father noted down the date of the birth and the death of his children - a heartrending story encapsulated in a few handwritten notes. A letter extant in the Lambeth Library shows that John Mező was still alive in 1763, and it must have been a decade or two later that Granville Sharp bought his Hungarian Bible for the British and Foreign Bible Society, of which he became the first President (Gömöri, 2004, 3).

Hungarian poetry was first written in Latin - Trinity owns a book of verse by Janus Pannonius, the first outstanding poet born on Hungarian soil. In the 17th century some of the best Latin poets were anthologized and both in Trinity and the University Library we can locate the popular anthology Delitiae Poetarum Hungaricarum (Frankfurt, 1619) edited by David Pareus's son, J. P. Pareus. That century also yields books on Hungarian history such as Martin Fumée's great compendium The History of the Troubles of Hungariae, translated from the French in 1600, János Bethlen's Rerum Transylvanicarum libri quattor (Amsterdam, 1664), also John Shirley's book with the evocative title The History of the Wars of Hungary (London, 1685), the latter owned by Henry Newton, no relation of Isaac. Trinity also has a copy of John Stoughton's millenerian Felicitas ultimi saeculi, 1640) dedicated to György Rákóczi I. - it bears the name of a "Joh. Tholnai", but it is by no means certain that the owner was identical with the Puritan Church reformer János Dáli Tolnai (1606-60). 
Amongst the numerous Hungarians who visited England in the 17th century, there was one György Csipkés Komáromi-Comarinus who visited Oxford in $1651 / 52$, and after obtaining a doctorate in Utrecht returned to Debrecen. His numerous publications include the first English grammar for Hungarians (Anglicum specilegium, 1664) of which no copy survives in the British Isles. Ten years earlier, however, Komáromi wrote a Hebrew grammar, Schola Hebraica (Utrecht,1654) of which Trinity has a copy (F.7.12). There is no inscription in this book but Newton's college was visited in 1655 by another Hungarian Calvinist theologian, Sámuel Köleséri The Elder. We know of his visit from an inscription in a small disputation, De Christi potestate presided by the influential Protestant theologian Coccejus (Leyden, 1655). Köleséri must have been a good Hebraist, most likely enjoying the support of John Arrowsmith, Professor of Theology and (at the time) Master of Trinity, for in the inscription mentioned above (Tracts.I.4.4-12) he claims to have used the College library with much profit: "Nobilissimum ac Excelentissimum Collegium (in cujus Bibliotheca dulcissimos librorum exsuxit fructa)" (Gömöri, 1989, 80). As no exact date is given, we can only surmise that Köleséri visited the College before or during Michaelmas Term 1655 , for there is another booklet purchased in Cambridge which the Hungarian scholar sent to a friend then studying in Utrecht: Irenodia-gratulatoria... Oliveri Cromwelli, published in 1652, where he did give the date: September 20, 1655. This rather rare booklet shows Sámuel Köleséri's sympathies which clearly lie with the Commonwealth rather than with the Royalists.

In connection with this Hungarian scholar one should also mention his son, a colourful character and real polymath. Sámuel Köleséri the Younger studied in the Netherlands, first in Leyden, then at the Calvinist University of Franeker, where he obtained a doctorate in Theology. He visited England in 1683, in the very year when his father passed away in Hungary. Apart from London he might have visited Cambridge as well, but we have no evidence of such a visit. When the already consecrated younger Köleséri returned to his homeland, at his very first sermon disaster struck: he could not remember the words of the Lord's Prayer. This gaffe distressed him so much that he went abroad once again, studied medicine at one of the German universities, returning to Hungary with a medical degree. In 1688 he became imperial Inspector of all the mines of Transylvania. He wrote a book on the gold mines which arose much interest abroad (Auraria Romano-Dacia, 1717) and corresponded with a number of foreign scholars, including Sir Hans Sloane. As a result of his letters now in the British Library, and also, it has to be said, on the strength of Köleséri's gift to Sloane, a Transylvanian gold nugget sent to London from Vienna in 1729, the generous benefactor was duly elected Member of the Royal Society in October of that year (Gömöri, 1991, 104). Köleséri, by the way, thought very highly of Newton - in his library there 
was a copy of the 1714 Amsterdam edition of Principia Mathematica (Bertók, 1955, 162).

Apart from the bibles mentioned earlier - and these were only some of the bibles in the University Library - it has a number of interesting Hungarica, some of which were already exhibited by Timothy Penton in November 1997 in the Reading Room Corridor of the library. In 2004 during the Year of Hungarian Culture in England I also organised an exhibition in the same space. As mentioned before, this was confined to early Hungarica (the 1996 exhibition had only 13 items published before 1800). Whereas the University Library has only modern collections of Janus Pannonius, it boasts a 1488 edition of Chronica Hungarorum by János Thuróczy, the sermons of the Franciscan Pelbárt of Temesvár, also István Werbőczi's Tripartitum (Vienna, 1561). The latter is in fact part of a codex (Add.8686), Werbőczi s codification of Hungarian laws being interleaved with extensive MS material in Latin and Hungarian. The library acquired it some time in the late 1980s and I was asked to catalogue it which led to a lucky find - to the discovery of a copy of a hitherto unknown letter in Hungarian by Archbishop Péter Pázmány to György Rákóczi I. of Transylvania. This letter was published in the Hungarian Irodalomtörténeti Közlemények of 1990, 5/6 - I hasten to add, this was not the only print or manuscript which I found in the rich holdings of the University Library. A fairly rare 16th century print also in the library is Historia obsidionis et oppugnationis Arcis Zigeth in Ungaria by Captain Horváth Márk, published in 1567 in Wittenberg (Nr. 11 in Acton.b.54.42) - it relates the dramatic events of the preceding year, that is 1566 , when the castle of Szigetvarr with the famous captain Miklós Zrínyi, the grandfather of the poet Miklós Zrínyi fell to the army of Solyman the Magnificent who died in the last days of the siege.

Hungarian visitors began to arrive in substantial numbers to Cambridge some time in the mid 1620s. Their presence can be traced from the account books of various colleges - this I discovered many years ago and, consequently, worked my way through all the existing Account Books or Bursar's Books of Cambridge colleges. Here, usually, under the heading "Elemosynae" or "Minutae expensae" one finds the names of nearly all Hungarian and Transylvanian Hungarian visitors who were interested both in the writings of English Protestant theologians and in English (and occasionally Scottish) Church government. These visitors almost never matriculated (in Cambridge merely one, in Oxford four persons did it in the 16th to 18th century), for two reasons: matriculation was expensive, and a good Calvinist could not lay an oath on the thirty-nine articles of the Church of England. But come they did in fairly large numbers: for example, according to the testimony of the account-books, there were more than a dozen Hungarians in Cambridge in 1663, a bumper year for foreign visitors.

Some of them also donated books to the University Library. There was one Márton Z. Tállyai, an otherwise undistinguished Hungarian minister, who having 
published an anti-Arian tract in Leiden in 1634, during his visit to England gave the UL a signed copy of that book on July 2, 1634. Copies of Stephanus J. Tétsi's Virga Mosis (Leiden, 1646) and of the very popular The Conduct and Character... of Count Serini published in London, 1664, the biography and deeds of military commander and accomplished poet Count Miklós Zrínyi are both unsigned, unnotated but interesting Hungarica. Trinity also has a copy of the latter, and though we do not know the compiler's name (he hides his identity behind the letters O.C. which in my view could correspond to the abbreviation "Ortelius Continuatus"), it can be established that most of his information must have come from German and Dutch sources. Incidentally, in the 17th century it was fashionable to circulate portraits of outstanding commanders or kings from foreign parts - since Gábor Bethlen, ally of the deposed King of Bohemia, Zrinyi was the first one whose "likeness" could be purchased in London bookshops. (He also figures "iconographically" large in Henry Marsh's A History of the Turkish Wars... which ran into several editions from 1663 to late 1664 - Gömöri, 1999, 215-16).

"Molnariana" works of Albert Molnár of Szenc in the University Library include a 1646 New Testament in Hungarian as well as a collection of the Psalms of David (Szent David kiralynak es prophetanak 150 soltari) from 1650, both printed in Amsterdam. The library also owns a unique copy of a 1651 thesis written in Latin in the Netherlands. It is the doctoral dissertation of the great Transylvanian educationalist János Csere Apáczai from the new university of Harderwijk. De Primi Hominis Apostasia (Apostasy of the First Humans) is included in a collection of theological tracts (Nr. 11 in Syn.7.58.109) which also contains Utrecht disputations by two other Hungarians, Sámuel Enyedi and Istvan Némethi. Apáczai, author of the first encyclopedia in Hungarian (Utrecht, 1655), married a Dutch woman, but returned to Transylvania to teach there at the Academy of Alba Julia/Gyulafehérvár until he fell out with the reigning Prince who suspected him of having "independentist" views. As for the Harderwijk thesis, of which only a copy was extant in Hungary, it was discovered in 1975 when a Hungarian scholar, Imre Bán, learned from a Dutch colleague about its existence.

After a pause of about twenty years Hungarian history began to interest Englishmen once again at the time of the Turkish Wars of 1663-64; there are several entries relating to these in Samuel Pepys's diaries (mostly in the critical edition). After Nicholas Zrínyi's death and the shameful treaty of Vasvár of 1664 which left the Turks in possession of most of their conquests in spite the fact that they had lost the war, Hungarian noblemen started plotting with the Turk against their Habsburg King and Emperor. They were soon betrayed and the main culprits apprehended, tried and executed. All this is described in a book in the UL (Rel.e.67.2), a translation from the Latin or from German, probably financed by the Imperial Ambassador, for listen to the sumptuous title: The Hungarian Rebellion, or, An historical relation of the late wicked practices of the three counts, 
Nadasdi, Serini and Frangepani; tending to subvert the Government of his present Imperial majesty in Hungary, and introduce the Mahometan; with their arraignment, condemnation and manner of being executed for the same. Translated P. A. (London, 1672).

In the 18th century the University Library was visited and now holds three books by the eccentric Hungarian, György Kalmár. This man was an erudite Hebrew scholar from Debrecen who in the early 1750s published several tracts in Latin in Oxford and London, discussing minute problems of Hebrew philology. Later he published books in Geneva, and in Hungary such as Prodromus idiomatis (Pozsony, 1770) of which a copy signed for Regius Professor Thomas Rutherford is now extant - Rutherford was a Fellow of St. John's but his books were apparently bequeathed to the University Library. Kalmár, as many of his contemporaries and predecessors (John Wilkins, Francis Lodwick), was interested in a "universal language" which could have solved all the problems of mankind, and in 1753 circulated a leaflet entitled "Proposals for Printing by Subscription. An Universal Language: and that in a very extraordinary short-hand by George Kalmar" (BL, Add.4312.ff.1) - from this Proposal it looks that some serious English scholars were involved supporting this project which in the end came to nothing. (Kalmár already lists Hungarian as "a lesser used language... used in the greatest part of that Kingdom [of Hungary]" next to the Finnish!). It is worth noting that in the 17th century Hungarian was still a mystery to most linguists and one Ferenc Fóris Otrokócsi in Origines Hungaricae (Franeker, 1693) argued that it was related to Hebrew!

Apart from Trinity and the University Library, the next most interesting collection of Hungarica is probably in Emmanuel College. This was the college of William Sancroft, a great patron of foreign Protestants and, from the 1640s onwards, Hungarians. There is a long Latin letter in the Bodleian written by a Hungarian theologian, Péter N. Szerentsi (MS Tanner 66, fol.18), which shows the Sancroft indeed extended hospitality and possibly sent English theological literature to this particular Transylvanian visitor then based in London. Emmanuel owns about two dozen old Hungarica, starting with Sambucus's Emblemata (the 1584 edition), books by Szegedinus and Fegyvernekinus, the 1571 Wittenberg edition of the anti-Arian tract by Petrus Carolinus, Pannonius (Brevis Explicatio Orthodoxae and Fidei...) and, of course, John Stoughton's Felicitas, mentioned earlier. Sancroft drew some of his information on Hungary from Giorgio Tomasi's Delle guerre et rivolgimenti de Regno d'Ungaria, e della Transylvania, published in 1621 (335.5.5) and also from a 1601 edition of Botero (The Worlde or an historicall description), but his interest was clearly rekindled at the time of the Turkish Wars of 1663/64, for Emmanuel has more than one books on the subject (A brief account of the Turks late expedition... and Samuel Clarke's A prospect of Hungary and Transylvania). Members of the small London colony of Hungarians 
after the Restoration also donated books to Sancroft - these included the phenomenally succesful Hungarian philologist Georgius Sylvanus/Szilágyi whose Latin translation of Isocrates (1676) is in Emmanuel Library, which also holds the "English variant" of Johannes Mezőlaki’s De idolatria pontificia (Utrecht, 1670), as the name indicates, a sharp polemic against Roman Catholics (S.14.3.1(9)). Knowing the orientation of the college it is no surprise that Emmanuel has an account of the sufferings of those Hungarian Protestant ministers whom the Habsburg authorities first forcibly tried to convert to Catholicism and when that failed sold as galley-slaves to the Neapolitans. (They were eventually freed by the threat of a battleship commanded by the Dutch Admiral Ruyter.) The case for the persecuted ministers was put forward in A short memorial of the most grievous sufferings... etc. which, in 1676, surely did not contribute to the popularity of the Duke of York, soon afterwards a convert to Catholicism. Finally, Emmanuel has a copy signed by Pál Gyöngyösi $a k a$ "Christophorus Dialithus Ungarus". Gyöngyösi, who hid his identity under an easily decipherable pseudonym, published his ostensibly anti-Arian but also strongly anti-Catholic work Kreszmodia Parabolico Prophetica de Infausto Fausti Socini in Oxford, where for a year he enjoyed the hospitality of Gloucester Hall. After the book's publication Gyöngyösi proceeded to Cambridge where he donated his book inscribed to local scholars, including a Mr Balderston, Master of Emmanuel (327.6.63). On his return to Hungary Gyöngyösi got into trouble with the authorities who confiscated a large number of his books. This measure was quite understandable, if we know what sort of literature the Hungarian minister attempted to smuggle back into Hungary - numerous copies of a theologico-political pamphlet written by Benjamin Woodroffe of Oxford against the Protestant apostate Otrokocsi.

Most Cambridge colleges have copies of the Unitarian György Enyedi's Expliciationes Locorum Veteris, first published in 1598 and republished in Groningen in 1670. Apart from Emmanuel, Clare, Corpus Christi, Gonville and Caius, Peterhouse and St. Catharine's have copies, the latter where after the Restoration interest in anti-Trinitarianism was particularly strong, actually holding two copies. (All these are of the second edition, only Manchester College, Oxford and the British Library have copies of the rare first edition.) Speaking about anti-Trinitarianism, King's Library holds the copy of a book written by Ferenc Dávid, one of the founding fathers of Unitarianism: De falsa et vera unius Dei patris... published in 1569 at Alba Iulia (RMNy I: 254); the same book is extant at Clare's Library, too. Because Unitarianism partly originates from Transylvania, Hungarian and especially Hungarian Transylvanian students were considered "experts" on this particular "heresy" - an anti-Socinian seminar run by Vedelius at Franeker in the early 1640s consists almost exclusively of Hungarians. (Sancroft's Calvinist friend Szerentsi was also a student of Vedelius.) Hungarian 
Unitarians began to visit England after the restoration of the monarchy, but apart from the Groningen edition of Enyedi they did not bring "subversive" books into this country. My latest research found amazing proof of contacts in the 1660 s between the Royal Society of London and some Transylvanian Unitarians, contacts which eventually led to the publication of Edward Brown's famous travelogue and description of the Hungarian mines (A brief Account of Travels in Hungaria, etc. London, 1673).

Two more 17th century Hungarian bibles exist in Cambridge, one of which, Szenci Molnár's so-called "Hanau" Bible (1608) was the gift of Lancelot Andrewes, later on Bishop of Winchester to Pembroke College. The other one which is extant in Queens, bound in vellum as "Biblia Hungarica" is more interesting, for it contains an inscription: Johannes Madarasi, a Hungarian student sent this bible (printed in 1612), to the college from Amsterdam in 1630 with the following commendation: "Ad Bibliothecam illustrissimi Collegii Reginalis (ex qua suavissimos studiorum suorum flores excerpsit) in perpetuam memoriam gratitudinisque debitae symbolum, Praefecto R. ac Clariss. Joanne Mansel durante, lubens meritoque mittit...". Madarasi could not have spent more than one or two terms in Cambridge, but - as we see it from his note of gratitude - enjoyed warm hospitality in the town of Whitaker and Sancroft. At the same time when he used Queens' library, a compatriot of his, Pál Medgyesi was also in Cambridge, reading Lewis Bayley's Praxis pietatis which in his translation became a veritable best-seller in 17th-century Hungary.

Speaking of William Whitaker, the otherwise modest Hungarian collection of Gonville and Caius has a copy of Johannes Sambucus/Zsámboki's Emblemata (Antwerp, 1566) with the possessor's inscription: "Gulielmus Whitaker possidet hanc libram" (F.22.21). Apart from this and another 16th century publication, Theoremata by Petrus Lascovius (Laskai Csókás Péter), Caius has but one 14th-century Hungaricum, that is the Sermones of Michael of Hungaria (Cologne, 1498). Sambucus also figures in the Hungarica of Peterhouse with an edition of Lucianus (Basle, 1563) and in St. John's with two editions of Emblemata (the 1587 and 1599 editions).

Two more colleges have interesting old Hungarica in Cambridge: Pembroke and St. John's. Pembroke, apart from the Hungarian Bible already mentioned and Nádasdy's Mausoleum, a collection on Hungarian history published in 1664, also owns an Elzevir edition of Respublica Hungariae (published in the 1630s), as well as a copy of Otrokocsi Fóris's Originae Hungaricae with an inscription by Johannes Tolnai for Pál Gyöngyösi. It is signed in Kensington, where Tolnai was Schoolmaster until his death in 1703 and where Gyöngyösi must have been staying before his return to Hungary. It shows that Tolnai - who props up more than once in Mihály Bethlen's Diaries as a very hospitable person - kept an eye on 
publications on Hungary during his long stay in England (he lived there for over three decades). We could surmise that he had in his possession János Nadányi's Florus Hungaricus published in English translation in 1664 and also the pamphlets on the tribulations of Hungarian Protestants in the sixteen-seventies. Pembroke also has two fairly rare tracts published in Leyden in 1648, both written by a Stephanus A. Szokolaeus, alias Szokolyai, a Hungarian from Debrecen and Szatmár (today Satu Mare in Romania) De Politia et Magistratu and De Potestate Ecclesiae (8.25.5). There is no trace of Szokolyai visiting England and it would be hard to explain why were his disputations included in this collection mainly devoted to students doing work under the guidance of Professor Constantine Caesar - maybe the donor, a certain Marcus Frank, knew him personally.

Amongst Pembroke's MS holdings, however, there is an interesting album amicorum which includes an entry of Hungarian interest. I have in mind the album of Abraham Ortelius (1527-98), a facsimile edition of which came out in Antwerp in 1967 edited by Jean Puraye. Ortelius was a Flemish geographer and map-maker whose Theatrum Orbis Terrarum is still referred to as "the first great atlas". He travelled to Frankfurt and Breslau (now Wrockaw) and London, and was also visited by a number of eminent European Humanists. Daniel Rogers wrote an ode to him, John Dee, William Camden and Pieter Breughel The Elder signed his album. As for Hungarian connections: Andreas Dudith, at that time already ex-Bishop but still Imperial Councillor, inscribed a note in red ink in Latin with a short quote from Ovid (Pembroke MS 2/11351/v) in Breslau, October 29, 1584. Other inscribers include the Frenchman Jacques Bongars and Flemish botanist Carol Clusius both of whom visited Hungary, as well as Hubert Languet, Philip Sidney's mentor in Vienna, one of the best informed diplomats of the day (120/v) who chided his young friend in a letter for not telling him about his intention to spend several weeks in Northern Hungary in 1573. Sidney's visit to Hungary is documented only by a sentence or two about Hungarian customs in the Defence of Poesie but his correspondence with Languet (which I have studied and analysed from a Hungarian point of view in my book Nyugatról nézve, Budapest 1990) shows that he had, indeed, a number of acquaintances amongst the Hungarian aristocracy. These included János Balassi, father of Hungary's greatest 16th century poet, Bálint Balassi.

St. John's Library has several books by Szegedi Kis and two editions of Janus Pannonius; it also has the younger Pareus's Hungarian poetic anthology in Latin. In this college the most friendly scholar with continental visitors, including Hungarians, was John Gunning - and it does not come as a surprise that one of the copies of the Nicholas Zrínyi biography of 1664 was owned by Gunning himself (Hh.1.12). Edward Browne's travelogue of Hungary published in 1673 exists in three copies in the library, one of the first and two of a later, extended edition. The 
two most active Hungarian scholars of Restoration England, Mezőlaki and Sylvanus/Szilágyi both knew Gunning and presented him with books, consequently St. John's has signed copies of the first's De idolatria pontificia and the second's translation of Theocrit's eclogues into Latin. In fact, there are two copies in the library of Theocriti Syracusii... EIDYLLIA, for apart from the copy presented to Gunning (who by that time was elevated to the Bishopric of Ely) Georgius Sylvanus (perhaps while visiting the college) also signed a copy to a Fellow, Francis Roper (Gömöri, 1985, 115). One should perhaps mention the fact that although Sylvanus was a serious Classical scholar, and a shrewd businessman, his use of the title "Medicus" is probably unfounded - although he had studied before his arrival to England in Heidelberg and Basle, the line of his studies was theology, not medicine.

I would like to round up my essay with an anecdote illustrating the extent of my research for Cambridge Hungarica. When visiting the Folger Library of Washington, D.C. I noticed the erroneous dating of a 17th century book - Johannes Adami's bilingual Londinum Perlustratum, a long poem praising London reborn after the Great Fire. Folger's cataloguer obviously used the British Library dating which was also wrong. When I brought this to the attention of the Librarian - she asked me in a somewhat surprised tone: where do I know from the right date of publication? Well, I said, King's College Library in Cambridge actually has a copy where the date on the title-page (1670) is not blurred or obliterated. She thanked me for the advice and the Transylvanian Adami's eulogy of London-Troynovant was immediately properly re-dated.

\section{References}

Bertók, 1955: Bertók, László ‘ifj. Köleséri Sámuel könyvtára’ (Debrecen: A debreceni Kossuth Lajos Tudományegyetem könyvtárának Évkönyve,1955/II, Könyv és könyvtár).

Gömöri, 1978: Gömöri, György 'Szenci Molnár Albert mủvei és bibliakiadásai cambrigde-i könyvtárakban’ in Szenci Molnár Albert és a magyar késö-reneszánsz (Szeged, 1978).

Gömöri, 1985: Gömöri, György “George Sylvanus - A 17th Century Classical Philologist” in Angol Filológia Tanulmányok - Hungarian Studies in English, Vol. XVIII (Debrecen, 1985).

Gömöri, 1989: Gömöri, György Angol-magyar kapcsolatok a XVI-XVII. században (Budapest: Akadémiai Kiadó, 1989).

Gömöri, 1991: Gömöri, György Erdélyiek és angolok. Müvelödés- és kapcsolattörténeti tanulmányok (Budapest: Héttorony, n.d. [1991]).

Gömöri, 1993: Gömöri, György ‘Magyar kézírásos szöveg a XVII. századbeli Angliában’ Magyar Nyelv, 1993, No. 2.

Gömöri, 1999: Gömöri, György A bujdosó Balassitól a meggyászolt Zrínyi Miklósig. Tanulmányok (Budapest: Argumentum, 1999).

Gömöri, 2004: Gömöri, György ‘Egy 18. századi magyar Londonban’ Magyar Könyvszemle, 2004, No. 3. 
Packard, 1790: Peter Peckard Memoirs of the Life of Nicholas Ferrar (London, 1790).

Pongrácz, 1914: Pongrácz, József Magyar diákok Angliában (Supplement from Jókai kör 1912/3 évkönyve, Pápa, 1914).

RMNy I. 1971: Régi Magyar Nyomtatványok,1473-1600 (Budapest: Akadémiai Kiadó, 1971).

ÚMIL I. 1994: Péter, László (ed.) Új magyar irodalmi lexikon, A-Gy (Budapest: Akadémiai Kiadó, 1994). 